\title{
Beyond Dichotomies
}

\section{Re-Assessing Gender History and Women's History in Canada}

\author{
Joan Sangster
}

Canadian women's history, though relatively new in the history of the profession, is now considered by some to be passé, past its prime, out of touch with the realities of the postmodern world of the 1990s. In fact, there is also a new interpretation of the historical evolution of Canadian women's history emerging, which situates women's history in the one dimensional past, gender history in the three dimensional future.

This is the way the story goes. First, there was old-fashioned history, in which political, military and economic themes relating to men and the public sphere dominated. Then, in the 1970 s, a challenge to that history came from a group of younger and junior members of the profession, feminists who wished to re-establish women's place in history by recovering, analyzing and understanding women's past, which, the story concedes, had been marginalized and trivialized in the reigning historical interpretations.

Although these early feminists were correct in seeing a masculine bias in history, the narrative continues, they were still limited in their outlook, and their writing was problematic for a number of reasons. They produced a history which was "compensatory", and like the older male-dominated history, represented only one piece of a more complex jigsaw puzzle. They simply "added" women to the existing historical stew and "stirred", without really questioning all the ingredients of history." They still took men as the measure, concentrating on women, and especially WASP women, in the public sphere. Moreover, they "limited" themselves to descriptions of women's "experiences" rather than analyzing "shifts in the relations between

1 As feminist historian Karen Dubinsky has pointed out, this wording is used by some gender historians to characterize the earlier project of women's history. Karen Dubinsky "Gender and History," History colloquium, Trent University, 15 March 1995.

Joan Sangster, "Beyond Dichotomies: Re-Assessing Gender History and Women's History in Canada," left history, 3.1 (Spring/Summer 1995), 109-121. 
masculinity and femininity, thus examining the whole social formation not just women." 2 Their perspective was by definition limited: they "took for granted a unitary category (women) and then proceeded to document its history," but ignored shifting relations among race, gender and class. ${ }^{3}$ They were not sufficiently theoretical, and too often they created "middle class heroines and working-class victims" out of women. They missed the "multilayered' and fractured nature of consciousness, instead "mistaking all agency on the part of the oppressed as resistance." In short, this approach missed a crucial point: a truly innovative approach to history looks not just at women, but at gender relations in general.

Now, the story continues, gender history offers a "more theoretically sophisticated" point of view. The analytical category is gender; the theoretical debts often incline towards post-structuralism, viewing other feminist or certainly Marxist approaches more critically. Gender, unlike the narrow concentration on women, will open more complex, multilayered, and revealing doors to history. Women's history is out; gender history is in.

This narrative is interesting for a number of reasons. First, unlike the decentering which post-structuralist analysis claims to embrace, this story posits a linear, progressive, almost Whiggish view of the evolution of women's history. History moves from the meagre and partial insights "limited" to women in the earlier period to the more penetrating and profound "integrative" insights based on gender in recent times. ${ }^{5}$ A hierarchy of interpretation emerges: women's history is inadequate in that it 'marginalizes' women, while gender history offers a superior and more 'holistic' analysis. Even the claim that women's history promoted a feminist interpretation is contested for in this new hierarchy only gender history can truly accomplish this objective; as one proponent notes, "feminist history is more important than women's history ... [for] feminist history is about gender, not women."

2 Lykke de la Coeur, Cecilia Morgan, Mariana Valverde, "Gender Regulation and State Formation," in Allan Greer and Ian Radforth (eds.) Colonial Leviathan: State Formation in Mid-Nineteenth Century Canada (Toronto 1992), 165.

3 Ibid.

4 K. Dubinsky et al, "Introduction," in F. Iacovetta and M. Valverde (eds.), Gender Conflicts: New Essays in Women's History (Toronto 1994), xviii. It is not clear which feminist historians are being critiqued here, as there are no citations for some of these characterizations. Indeed, the only citation for this 'erroneous' view of resistance is for (an older book) on working class history, Bryan Palmer, A Culture in Conflict: Skilled Workers and Industrial Capitalism in Hamilton, Ontario, 1860-1914 (Montreal 1979).

5 Lynn Marks, "Ladies, Loafers, Knights and Lasses: The Social Dimensions of Religion and Leisure in Late 19th Century Small Town Ontario," PhD Thesis, York University (1992), 27.

6 Mariana Valverde, The Age of Light Soap and Water:Moral Reform in English Canada, 1885-1925 (Toronto 1991), 12. This quote, of course, is confusing: it could mean that women's history is ALSO simultaneously gender history. 
Contrary to any post-structuralist claim that metatheories are being displaced, this interpretation creates a new theory of gender which makes a claim to represent a superior method of analysis. While people who speak about this "transition" to gender history often emphasize that the project of women's history is not finished, that important work has been and still needs to be done, their language betrays a condescension towards practitioners of women's history: adding women to history is referred to as the "Polyfilla" approach; gender history is more "theoretically sophisticated"; gender history goes "far beyond" women's history, and so on. Indeed, the way of describing the question is revealing: the fact that gender history is "new" and women's history is "old" constructs the latter as the aged and tired Clio in decline.

Secondly, binary oppositions are not interrogated, but rather are blended into this story. The older women's history is juxtaposed to the consumer choice of the younger, more hip generation. Partial insights are contrasted to profound insights; a marginal history is contrasted to a more encompassing history. Many analyses often note that doing women's history is still a 'good thing' and they concede that a critique of women's history as marginal and partial has long been articulated by many conservative members of the historical profession - usually those who are hostile to the teaching of women's history and to feminist critiques of history. Feeding the flames of anti-feminism by repeating these views, they admit, could be dangerous. ${ }^{7}$

Nonetheless, the emphasis on gender as a superior mode of analysis persists. In recent conferences and talks, more than one speaker has articulated precisely this hierarchy of gender over women's history when introducing papers. ${ }^{8}$ What do we make of it? Are those who resist it simply outdated and past their analytical prime, unable to admit that mothers' wisdom should be supplanted by daughters' ideas? Is this really a generational conflict at all, or rather, is it an ideological one, based on different understandings of feminism, different theoretical approaches to the study of history? Are newer analyses based on gender more theoretical than the women's history of the past? Should we take the emphasis on gender to heart and abandon women's history courses, assuming that it has done its consciousness raising work, and we can now move on to a higher plane of analysis?

I want to suggest that we abandon some of the binary oppositions in this perspective: we need to re-examine the Canadian women's history which was actually written over the last twenty years as well as the current direction of gender history, then assess the theoretical and political underpinnings of both.

7 K. Dubinsky et al, "Introduction" in Gender Conflicts. Indeed, the comment that we need not women's but gender history is precisely the comment I've heard as an excuse not to teach women's history at all by some conservatives.

8 This was evident at the Second International Carleton University Conference on the History of the Family, Ottawa (May 1994). 


\section{2 left history}

We may actually find more overlapping continuities, similarities and problems than stark contrasts and oppositions.

This debate about the relative merits of gender versus women's history has been going on for some in the United States and Britain. Judith Bennett and Joan Hoff, publishing in Gender and History and Women's History Review have both critiqued what they see as the negative effects of the "bandwagon"9 of gender history, though in Hoff's view, this trend is closely linked to the rising star of post-structuralism. Bennett takes issue with the emphasis on gender history as superior to women's history in part because she sees this as an attempt to curry academic respectability and abandon a more 'political' and feminist women's history, in part because she feels a critique of patriarchy is being abandoned with the turn to gender history. Similarly Hoff, clearly influenced by a radical feminist perspective, sees the emphasis on gender history tied to post-structuralist discourses which downplay concepts of women's lived oppression in favour of endless deconstruction and apolitical theorizing. ${ }^{10}$

One attempt to move beyond the "impasse of gender versus women's history" is made by Louise Newman, who recognizes that simplistic typecasting of women's history as "theoretically naive" and gender history as politically "irrelevant" by opposing sides is not very useful. Unfortunately, Newman's definitions of women's history and gender history also tend to collapse the former project into the study of 'experience' and the latter into explorations of 'representation'. While Newman is correct in pointing out that the two are inseparable, her solutions ultimately favour a culturalist perspective which inclines towards post-structuralism. ${ }^{11}$

I would agree that there is a strong post-structuralist component to some of the recent work in gender history; as Canadian historian Cecilia Morgan admits: "closely tied to poststructuralist work is the development of gender history." ${ }^{2}$ Post-structuralist theory, she continues, tends to unsettle historians by questioning existing humanistic notions of historical experience; indeed, describing women's experiences is now seen as somewhat 'declasse' to histo-

9 Margaret Hobbs, refering to the Benett debate in "Gendering Wòrk and Welfare: Women's Relationship To Wage-Work and Social Policy in Canada During The Great Depression", PhD. Thesis, University of Toronto, 1995, 29.

10 Judith Bennett, "Feminism and History," Gender and History, 1.3 (Autumn 1989) and Joan Hoff, "Gender as a Postmodern Category of Analysis," Women's History Review, 3.2 (1994).

11 Louise Newman, "Critical Theory and the History of Women: What is at Stake in the Deconstruction of Women's History?" Journal of Women's History, 2.3 (Winter 1991).

12 Cecilia Morgan, "The Use of Theory in Teaching Women's History," in Bettina Bradbury, et al (eds.), Teaching Women's History: Challenges and Solutions (forthcoming, Edmonton 1995). 
rians more interested in "excavating the meaning of gender identities." 13 In contrast to some previous feminist writing, much post-structuralist theory emphasizes the construction of subjective identities and the difficulty of making firm generalizations about women's oppression, given the shifting, multiple and competing allegiances of age, class, marital status, ethnicity, religion etc. As one Canadian historian of leisure puts it: "we can not privilege any one group identity, but rather we need to trace the inter-relationships between gender, age, class and marital status" 14 for men and women. One can see why this kind of 'hedging' irritates other feminists concerned with critiquing what they see as the dominant structures of power, and oppressive power at that, whatever its material, racial or gender basis.

Few if any critics have approached this debate about the relative 'merits' of gender and women's history from a Marxist or socialist-feminist perspective. Indeed, when I began to think about this, a socialist-feminist critique of gender history appeared to be a contradiction in terms. Unlike Hoff and Bennett, socialist-feminists never insisted on the primacy of gender over class in all historical analyses and we maintained a healthy scepticism about overly deterministic theories of universal patriarchy. Increasingly, socialist feminist writers have argued for a historical approach which did not privilege any one axis of oppression, but instead saw them as interdependent, varying according to the particular historical and social conjuncture.

At the same time, socialist-feminist historians were never afraid to mount a political, engaged version of events, which took the very real economic and social oppression of women as objective 'truths' (unlike some later post-structuralist analyses). And for all its many faults, (and I admit there are many) a Left-inspired approach to women's history at least understood that there WAS a 'woman question', that women's oppression needed analysis as an objective problem, and that women, because of previous marginalization, needed their own space to write, speak, analyze and organize without the presence and dominance of male theoreticians. Ironically, this emphasis on the crucial need for separate space for women's history is being downplayed with the new emphasis on gender history. The unintended and dangerous consequences of the emphasis on the superiority and 'academic respectability' of gender within the academy, as Bennett argues, may be that women's history will be disdained or that the feminist, political, and emancipatory edge to women's history will be dulled.

To some extent, I do think the emphasis on gender is all for the better since it is often accompanied by an insistence on the importance of integrating

13 Bryan D. Palmer, "Canadian Controversies," History Today, 44.11 (November 1994), 48.

14 Lynn Marks, "Ladies, Loafers, Knights and Lasses," 28. 


\section{4 left history}

race and ethnicity into our analysis of women's past - though surely a race analysis can be an essential part of women's history as well as gender history. ${ }^{15}$ Certainly, the most important recent transformation in our understanding of women's history has been the pressure to adopt a more inclusive analysis, which takes account of ethnicity, race and sexual orientation in women's lives. Unfortunately, though, sexual orientation is often ignored as feminists themselves admit - in favour of race and ethnicity (at least in published works to date). ${ }^{16}$ These attempts to construct a more thorough going race analysis for all women's history is certainly an 'advance' if we want to speak in linear terms, though I will suggest below that we have retreated in other areas.

Moreover, the emphasis on identity construction which comes as part and parcel of the new attention to women's diverse backgrounds, may have come with some political contradictions, at least for socialist-feminists: it is linked to a post-structuralist inclination to deconstruct 'woman,' emphasizing the fractured and multiple identities of women, rather than identifying some of the objective and material structures of economic and state power which so clearly shape women's lives in an oppressive manner. This has become apparent in my undergraduate teaching; in trying to grapple with such theory, students often stress the meaning of woman's personal 'identity' as the sine qua non of a feminist analysis, without asking what structural forces shaped collective identities. Moreover, I think it is wrong to characterize a concern with class, and to a lesser extent ethnicity, as simply a 'generational' difference in approach, with junior historians suddenly aware of a story the old generation totally missed. This is far more apparent in terms of race, and one could make a strong argument that both Canadian women's and gender history have far to go in terms of writing comprehensive histories which include Native women and women of colour. Recent works on women, gender and ethnicity have enriched our understanding immeasurably, though a concern with culture (including English/French differences) and ethnicity was not totally absent until the 1990 's.

On the question of class, a quick perusal of Diana Pedersen's excellent bibliography on women's history is revealing: articles dealing with class are

15 Path-breaking research on Native women published fifteen years ago is evidence of this point. See Sylvia Van Kirk, Many Tender Ties: Women in Fur Trade Society, 1670-1870 (Winnipeg 1980) and Jennifer Brown, Strangers in Blood: Fur Trade Company Families in Indian Country (Vancouver 1980). The example of American women's history would also indicate that race and ethnicity can be a central part of women's history. Earlier books such as Jacqueline Jones, Labour of Love, Labour of Sorrow (New York 1985); Dolores Janiewski, Sisterhood Denied: Race, Gender and Class in a New South Community (Philadelphia 1985); Vici Ruiz, Cannery Women Cannery Lives: Mexican Women, Unionization and the California Food Processing Industry, 1939-50 (Albuquerque 1987) or recent readers like Ellen DuBois and Vicki Ruiz (eds.), Unequal Sisters: A Multicultural Reader in U.S. Women's History (New York 1990) make this clear.

16 Karen Dubinsky "Diversity in Women's History" in Bettina Bradbury et al. (eds), Teaching Women's History. 
actually quite numerous. From the 1970 's on, many feminist and socialist authors examined wage work, the family economy and the labour movement or critically explored middle-class/working-class relationships. Bettina Bradbury makes a similar point in a recent review essay on the history of women and work. ${ }^{17}$ In the 1970's and 1980's, Canadian historical journals like Labour/Le Travail and Histoire Sociale and many collections of articles like Women at Work, and Not Just Pin Money included material on workingclass women; as Veronica Strong-Boag notes, integrating a class analysis into women's history was quite central to the 'project' of feminism in that time period. ${ }^{18}$

For this reason, I think the narrative which sees earlier women's history as focusing on Anglo "middle class heroines" as something of a caricature. The rejection of class, perhaps more evident in the U.S., was not so evident in our writing, a reflection in part of the different politics of the Canadian women's movement. And some of this older research on working-class women remains relevant today, and in fact, could inform ongoing research. Wayne Roberts and Alice Klein's article on the regulation of the working 'girl' in Toronto, for instance, sketched out some important themes dealt with later by Carolyn Strange, though the latter has made use of Foucaultian concepts rather than the Marxist class analysis used by Roberts and Klein to explain this regulation. ${ }^{19}$

The question of middle class/working class relations was also broached, even within published work which dealt with middle class women's organizing. ${ }^{20}$ The earlier treatment of the suffrage movement by Carol Bacchi, for

17 Bettina Bradbury, "Women and the History of Their Work in Canada," Journal of Canadian History, 28.3 (Fall 1993).

18 Veronica Strong-Boag, "The Challenge of Fairness: Thinking about Canada's Two Feminist Waves," paper presented at Colloque 'Feminismes et cultures politiques nationales,' Lyons, France (1994), 4.

19 Alice Klein and Wayne Roberts, 'Beseiged Innocence: The 'Problem' and Problems of Working Women, Toronto, 1896-1914" in Janice Acton, et al (eds.), Women at Work: Ontario, 1850-1930 (Toronto, 1974); Carolyn Strange, "The Perils and Pleasures of the City:Single Wage-Earning Women in Toronto, 1880-1930," PhD, Rutgers University (1991).

20 Recent calls for gender history often suggest that such 'relational' analyses never existed in the past. Yet note earlier articles such as Wendy Mitchinson, "The YWCA and Reform in the 19th Century," and Christina Simmons, "Helping the Poorer Sisters: the Women of Jost Mission, Halifax, 1905-1945," Histoire Sociale/Social History, 12.24 (Nov. 1979): these were concerned with social relations between women of different class backgrounds. Interestingly, the way in which Canadian women's history is now portrayed in the international scene is conditioned by these claims that the earlier women's history was very politically 'limited.' In a review of Gender Conflicts in the Women's History Review the British reviewer opens by declaring that "in the past women's history in Canada has been characterized by liberal and middle class biases ... [authors'] focused on white women, exploring their contribution and ignoring their class biases." Women's History Review, 3.3 (Winter 1994). 


\section{6 left history}

instance, addressed, though some would argue in too much of a social control paradigm, the ethnocentrism and very real class biases of early feminists, while other historians explored the ethnic identification of women activists or the ways in which language and culture contributed to the marginalization of French Canadian women. And feminist historians' political writings also tried to link sexism and ethnocentrism, as Ruth Pierson's 1984 review of The Great Brain Robbery indicates.

While earlier works like Bacchi's were justifiably critiqued for being overly schematic and regionally biased, they were not completely blind to ethnic and class differences between women. Indeed, Bacchi has been heavily criticized for ignoring the anti-patriarchal elements of suffragists' ideas in favour of their ethnocentric biases. ${ }^{21}$ More recent analyses of women's reform work, sometimes employing a Foucaultian analysis, and more attuned to race, have undoubtedly provided very important new insights on first wave feminists, though I am not convinced that the interpretation offered is fundamentally different. There is, I grant, some distinction between the middle classes' inculcation of ethnocentric, civic values in the immigrant and working class population (described by Bacchi) as opposed to the Foucaultian creation of 'moral' citizens through the symbolic representation of morality and the transformation of inner character (suggested by Valverde). But again, I find my students' analyses revealing: they see these interpretations as complimentary and indeed, they assume that Valverde has built on Bacchi's insights. In both analyses, they recognize, the authors are describing a hierarchy of power and dominant/subordinate relations of class and ethnicity which are worked out through the reform movement. And arguably, Bacchi's attempt to analyze reformers' desire to create a strong interventionist state introduced questions which still need exploration..$^{22}$

Secondly, the attempt to explore masculinity and to understand the totality of male female gender relations is also presented as an 'advance' from the 'older' women's history. It is true that insights gained from women's history

21 As Veronica Strong-Boag argues, early feminist reformers have tended to be condemned or critiqued; the context for, and contradictions of their sometimes radical, sometimes conservative thinking have rarely been stressed. Veronica Strong-Boag, "The Challenge of Fairness."

22 Carol Bacchi, Liberation Deferred: The Ideas of the English Canadian Suffragists (Toronto 1983) and Mariana Valverde, "When The Mother of the Race Was Free," in Gender Conflicts. (Admittedly the later does not analyze the writing of Canadian suffragists per se, but talks about the international intellectual feminist context they were situated in.) M.Valverde, The Age of Light Soap and Water:Moral Reform in English Canada, 1885 1925 (Toronto 1991). See reviews of Valverde in Bettina Bradbury, "Women and the History of Their Work," and Bryan D. Palmer "The Poverty of Theory Revisited: Or Critical Theory, Historical Materialism and the Ostensible End of Marxism," left history, 1.1 
have directly benefitted the study of masculinity: by emphasizing the "need to theorize the social construction of gender, the necessity of seeing women (and men) as socio-cultural groups and the use of gender as an analytical category," women's history paved the way for the new gender history which encompasses the study of masculinity. ${ }^{23}$

Is this topic, however, completely new? And what is the political message inherent in much of this new work on masculinity? Certainly, the attempts to theorize masculinity as socially constructed, not universal and natural, is useful. Still, we should not forget that some of the initial work in Canadian women's history actually made modest, initial attempts to understand the construction of masculinity: I am thinking of Barbara Robert's wonderful article on Creighton's John A Macdonald and his wives, Susan Mann's work on Henri Bourassa and Ruth Pierson's work on the double standard during World War II, all of which explicitly and implicitly addressed notions of male identity and its oppositional construction of female identity. ${ }^{24}$

I find it puzzling when historians claim that it was only after a good prod from Joan Scott and the post-structuralists that we ever considered masculinity. Until recently, writes one such Canadian historian, "paying attention to gender meant nothing more than discussing women""ss (a revealing pejorative comment, as if this was nothing!). Only under the influence of postmodernism, he continues, have we developed a more complex understanding of masculinity and femininity. This attributes more visionary influence to Scott (and to post structuralism) than is warranted - after all, Natalie Zemon Davies made a similar appeal to study male/ female relations years ago ${ }^{26}-$ and as his own analysis of male/female relations in the Cape Breton coalfields makes clear, gender identity must be tied to some old-fashioned concepts such as corporate power, class relations, and social conflict.

Also, as Deborah Gorham noted in a recent conference presentation, there is a disturbing tendency in some of the new work on masculinity (at least internationally) to look at the 'nicer' side of masculinity, exploring male (and more middle class) identities constructed through sport, education and family,

23 Editors Introduction to Gender and History, 1.1 (Spring 1989).

24 Barbara Roberts, "They Drove Him to Drink: Donald Creighton's Macdonald and his Wives," Canada: A Historical Magazine, 3.2 (December 1975); Susan Mann Trofimenkoff, "Henri Bourassa and the Woman Question," in A. Prentice and S. Mann Trofimenkoff (eds.), The Neglected Majority: Essays in Canadian Women's History (Toronto 1977) and Ruth Roach Pierson, They're Still Women After All: The Second World War and Canadian Womanhood (Toronto, 1986).

25 Stephen Penfold, "Have You No Manhood in You?: Gender and Class in the Cape Breton Coal Towns, 1920-26," Acadiensis, XXIII/2 (Spring 1994), 23.

26 Natalie Zemon Davis "Women's History in Transition: The European Case," Feminist Studies, 3.4 (Winter 1975). 
but avoiding the unpleasant questions of power, domination and patriarchy. There is a danger that historical work on masculinity will repeat one stream of the contemporary men's movement, which urges men to 'reclaim their tears' but ignores men's power and women's oppression. In many Canadian works, masculine identity remains one dimensional or underexplored; it may be presented as an understandable reaction to difficult working conditions or as a laudable desire for a breadwinner's wage, but we have yet to develop a comprehensive analysis of masculinity which also integrates a discussion of heterosexism, masculine violence, power and hierarchy. ${ }^{27}$

The emphasis on understanding the totality of male/female relations in history is also commendable. As Ruth Roach Pierson and Alison Prentice noted over a decade ago, the ultimate goal of feminist history is the production of a more 'human' history which takes gender into account and compares women's and men's experiences. ${ }^{28}$ At the same time, the insinuation that past women's history precluded any gender analysis or somehow avoided even mentioning men seems to me a distortion. I still believe that Joan Kelly's views on gender history versus women's history are as relevant today as they were over two decades ago: women's history, she pointed out, is by its very nature relational. It is not ghettoized and partial as some imply because it necessarily makes comparisons between women and men, relates women to men, and shows how women's lives were created by, within and sometimes in opposition to the world of men. ${ }^{29}$

In many existing works on Canadian women's history, this 'relational' context is by necessity provided: in Marjorie Cohen's work on the family economy and the sexual division of labour or in Wendy Mitchinson's pioneering work on women's insanity, their relationships to male doctors, and the medical definitions of female sexuality, gender relations are the background, while women are in the foreground of their analyses. In some areas of historical analysis, such as the family, social reproduction and the state, gender has also already been a central theme, even though these areas have been more

27 For some discussion of masculinity see Craig Heron, Working In Steel: The Early Years in Canada, 1883-1935 (Toronto 1988), 50, 92; Franca Iacovetta, Such Hard Working People: Italian Immigrants in Postwar Toronto (Montreal 1992), 75-6. As Steven Maynard notes, most works to date do not critically interrogate heterosexual masculine identity. See his "Rough Work and Rugged Men: The Social Construction of Masculinity in Working-Class History," Labour/Le Travail, 23 (1989).

28 Alison Prentice and Ruth Roach Pierson, "Feminism and the Writing and Teaching of History," Atlantis, 7.2 (Spring 1982). (Of course, for some post-structuralists, the concept or exploring 'experience' is now seen as somewhat naive.)

29 Joan Kelly, Women, History and Theory (Chicago 1984). 
often taken up by political economists and sociologists, whose theorizing, I should add, has not been unimportant to historians. ${ }^{30}$

In some ways the juxtaposition of gender over women's history is puzzling: I find few people demanding that working-class history cannot be taught any more unless we simultaneously teach middle-class or ruling-class history along with it. ${ }^{31}$ Nor do we hear calls for Black studies to be collapsed into race studies. Why then do we assume that women's history is no longer a viable, distinct subject or that historians cannot concentrate on women without also speaking of men? The recent critique of a book on the history of motherhood for failing to address fatherhood as well seems to me to reflect this fashionable, but sometimes misguided academic imperative of gender over women. ${ }^{32}$ I find few studies of masculinity making the same claim that women must be integrated into their analysis; instead, masculinity, it is presumed, can stand on its own.

It is also worth thinking about what we have lost, as well as what we have gained along with the new emphasis on gender history. While many studies of 'gender' (which like Gender Conflicts concentrate on women nonetheless) are more sensitive to the local and particular contexts of Canadian history, there appears to be less interest now in coming to terms with the national question and how French and English women's histories and historians can and should relate. ${ }^{33}$ Older collections, which might be faulted for their emphasis on the public and private spheres and on white women, nonetheless took some care to address - however marginally - the lives of Quebec women. Nor have we integrated, in a substantial way, the regional differences in women's lives occasioned by economic underdevelopment.

I also do not think that theory is somehow 'new' to gender history, but previously absent in women's history. The suggestion made recently by a

30 Much early work on gender, class and the state was done by political economists and sociologists. For example, see some of the articles in Heather Jon Maroney and Meg Luxton, Feminism and Political Economy: Women's Work, Women's Struggles (Toronto 1987); Jane Ursel, "The State and the Maintenance of Patriarchy" in James Dickinson and Bob Russell (eds.), Family, Economy and State: The Social Reproduction Process under Capitalism (Toronto 1986); or the recent collection by M. Patricia Connelly and Pat Armstrong (eds.), Feminism in Action: Studies in Political Economy (Toronto 1992).

31 Although this is suggested recently by a labour historian reviewing a book on working class history. Was he influenced by gender history arguments? See Craig Heron, review of Working Class Experience in left history, 1.1 (Spring 1993), 115.

32 James Snell review of Katharine Arnup's Education for Motherhood in Labour/Le Travail, 34 (1994), 310.

33 See Joanne Burgess' comments on this in J. Sangster, "Facing Our Differences, Forging Alliances: The Challenges of Creating an Inclusive Curriculum," in Bettina Bradbury, et al, Teaching Women's History. 
labour historian in an international publication that new Canadian works in gender history are more theoretically grounded than the older (more pedestrian?) women's history is rather insulting to those of us who did the 'older' women's history. ${ }^{34}$ Can one say that Ruth Pierson's earlier work on women and the state was not informed by feminist theory, or that those of us writing about women and socialism were not informed by Marxist feminist theory? On the other hand, some of the recent articles and books are not necessarily self consciously and exhaustively theoretical; many are grounded in fine, 'traditional' empirical methods - and that is not necessarily a bad thing for these are excellent studies! ${ }^{35}$

Gender historians are often interested in interdisciplinary studies and in feminist and post-structuralist theory, but to some extent, we have simply changed the kind of theory we are reading and writing. So, in reality, these lines of theory/non-theory are blurred, with generation and subject matter less indicative of a 'theoretical' approach, than the inclinations of the individual historian.

Indeed, I do not see a definite age split with a first generation of scholars doing women's history and a second generation doing gender history; again, the lines are blurred. One of the path breaking books on gender history, The Gender of Breadwinners is written by Joy Parr, an established historian, while recent work by historians like Katharine Harvey, Karen Dubinsky and others on violence against women concentrates on women's experiences and does so from a strong feminist perspective. ${ }^{36}$

As Cynthia Comacchio has effectively argued, claims that the 'new' emphasis on gender history always delves into uncharted areas, or uses entirely new methods (and supposedly rejects the 'old' simplistic dichotomies which see women as heroines or victims) are exaggerated. In effect, both the old women's history and some of the new gender history (if we even accept that dichotomous designation) are often wrestling with the same "dance of power. ${ }^{\prime 37}$ Power, it is true, is now being explored in new places and often with

34 Bryan Palmer, "Canadian Controversies" in History Today, 44.11 (Nov. 1994). Admittedly this is not the major thrust of the article which also argues that some of the new works in gender history are characterized by a certain 'parochialism,' and that Canadian history needs more synthesis.

35 Take for example, Franca Iacovetta, Such Hardworking People or Ruth Frager, Sweatshop Strife: Class, Ethnicity and Gender in the Jewish Labour Movement of Toronto, 1900-1939 (Toronto 1992), or Bettina Bradbury, Working Families (Toronto 1993).

36 Karen Dubinsky, Improper Advances: Rape and Heterosexual Conflict in Ontario, 18801929 (Chicago, 1993) and Kathryn Harvey "To Love, Honour an Obey: Wife Battering in Working-Class Montreal, 1969-79," Urban History Review 19.2 (October 1990) to name only a couple of examples.

37 Cynthia Comacchio, review of Gender Conflicts in Labour/Le Travail, 31 (1993), 373. 
some emphasis on its diffuse (Foucaultian) nature: as Bryan Palmer notes, gender historians tend to be "fixated less on power as it is exercised in parliament, than on how it is exercised through sexualities and gender identities." However, it would be far more useful to debate theoretical questions relating to how we should explore and analyze power - and overthrow it - than reproduce some tired platitudes about the superiority of gender over women's history.

There may be more continuity in the themes and problems we are encountering in both women's and gender history than we have acknowledged. Unlike other 'generations' (such as labour historians) who have tangled over interpretations of history, there may be more congruence and overlap, rather than disparity between the goals and approaches of gender and women's history - despite a narrative which suggests a linear progression and new 'turn' in approach. In both cases, there remains a strong sympathy for some form of feminist theorizing and an understanding that women's history, even if taught as a separate subject, cannot be reduced to themes of gender difference and oppression alone. Moreover, both are often pursued by historians with a political critique of the lingering masculine and ethnocentric persona of the profession.

Why then this new narrative which suggests, on the one hand, transformation, discontinuity and deconstruction of older ways, yet at the same time posits a Whig view of 'progress' represented by the turn to gender history? In actual fact, there are points of continuity, modification and continuing ideological proclivities between gender history and women's history. And there are points of common criticism as well: neither, one could argue, has effectively integrated an analysis of race and sexual orientation to this point. And there could be fruitful points of debate over what kind of theory, methods and analytical tools to use.

In the last resort, I find the references to women's history as marginal, narrow, or 'not enough' extremely troubling, both academically and politically. It may be that these references are offered as a means whereby new scholars can distinguish their scholarship from previous research, but we should avoid simple dichotomizing, and perhaps pay some respect to, as well as critique and build on the insights of past work.

"Women's history," Gisela Bock says, is simply "gender history par excellence." ${ }^{38}$ A common front, which does not disparage women's history, but instead thinks about using both a feminist and gender analysis constructively in the interests of creating a more critical history, should be our path forward. 